\title{
SMART Reflections on Policy Coherence, Legal Developments in the Netherlands and the Case for EU Harmonisation
}

\author{
Afterword to Erasmus Law Review Special Issue Towards Responsible Business Conduct in \\ Global Value Chains
}

Beate Sjåfjell \& Jeroen Veldman*

\begin{abstract}
The EU-funded project Sustainable Market Actors for Responsible Trade (SMART, 2016-2020), undertook an interdisciplinary and multilevel regulatory analysis of the barriers and possibilities for securing the contribution of private and public market actors to a sustainable future. Jurisdiction-specific contributions were an essential part of this broad regulatory analysis. This afterword reflects on the Dutch contributions included in this Special Issue, emphasising the urgency of securing policy coherence for sustainable business. The afterword highlights how individual initiatives by national legislators such as those of the Netherlands can be inspiring examples, while they also bring with them challenges including questions of scope and of legal certainty for businesses, specifically with regard to cross-border operations and activities. This leaves business with the difficult task of figuring out the various requirements and expectations and may lead to regulatory competition between EU member states. The afterword therefore concludes with a call for EU harmonisation, to give sustainability-oriented business a level playing field and provide legal certainty both for decision-makers in business and for those affected by the conduct of business across global value chains.
\end{abstract}

Keywords: sustainability, business, global value chains, planetary boundaries, sustainable corporate governance

\footnotetext{
Beate Sjåfjell is Professor, University of Oslo, Faculty of Law; Adjunct Professor, Norwegian University of Science and Technology, Faculty of Economics and Management. Coordinator of the now concluded H2020-funded project Sustainable Market Actors for Responsible Trade (SMART, 2016-2020), grant agreement 693642. Acknowledgment: This article draws on joint research in the SMART Project, and I am grateful to the whole team, and, in the context of this special issue, especially Jeroen Veldman for his leadership on the Dutch contribution to the project. Jeroen Veldman is Visiting Associate Professor at Rotterdam School of Management, Erasmus University Rotterdam, Visiting Associate Professor at Mines Paristech, Interdisciplinary Institute for Innovation, Paris and Section Editor Corporate Governance at the Journal of Business Ethics.
}

\section{Introduction}

There is increasing high-level policy commitment to sustainability worldwide. The corporate and financial risks of unsustainability bring home the significance of integrating sustainability throughout the business of any undertaking. Ultimately, the risk of continuing with 'business as usual' is existential. ${ }^{1}$ The global catastrophic risks of continued environmental degradation cannot be ignored, nor can the risks of continuing with exploitation of human beings and increasing inequality between and across jurisdictions. There are a number of scenarios that can lead to societal collapse, in none of which steady returns for investors or profitable business are very likely. ${ }^{2}$

Over the past decade, both states and corporate actors have had a widely acknowledged role to play in fostering environmentally and socially sustainable business in global value chains. The adoption of the United Nations Sustainable Development Goals (UN SDGs) in 2015, together with the Paris Agreement on Climate Change in the same year, has given a new impetus to the public discourse concerning what we need to do to achieve sustainability.

The growing concern with transitioning our societies to a sustainable future provides the basis for the European Green Deal as it focuses on a 'just transition' with the coordination of economic policies across the EU to integrate sustainability. ${ }^{3}$ Executive Vice-President Frans Timmermans underlined the need, in this context, for an 'ambitious Green New Deal for Europe, which

1. P.W. Keys, V. Galaz, M. Dyer, N. Matthews, C. Folke, M. Nyström \& S.E. Cornell, 'Anthropocene Risk', 2 Nature Sustainability 667-73 (2019).

2. B. Sjåfjell, 'The Financial Risks of Unsustainability: A Research Agenda'. University of Oslo Faculty of Law Research Paper No. 2020-18, Nordic \& European Company Law Working Paper No. 21-05, 29 June 2020, https://ssrn.com/abstract=3637969.

3. The European Commission, Communication from the Commission to the European Parliament, the European Council, the Council, the European Economic and Social Committee and the Committee of the Regions: The European Green Deal, 11 December 2019, COM (2019) 640 final. 
shapes the future for our children and ensures their health, prosperity and security on a green and thriving planet'. ${ }^{4}$ In line with this vision, issues concerning sustainability, including climate change, are informing regulatory debates in the areas of company law, reporting and finance, for instance in the EU debate on duties of the board, the role of 'double materiality' in reporting standards ${ }^{5}$ and the EU sustainable finance initiative.

However, much remains unclear with regard to the way in which corporations should or could fulfil their role, particularly with respect to the transnational activities of internationally operating business enterprises. This lack of clarity is as problematic for societies and for the transition towards sustainability, as it is for companies themselves. There is a growing international trend of filing lawsuits against companies and states for environmental or social harms. ${ }^{6}$ The sheer multitude of these cases presents an increasing liability risk. ${ }^{7}$ Harmonised requirements could help mitigate the resulting legal uncertainty and help give business a level playing field in the transition to sustainability. This is reflected in the business support for legislative reforms, as shown in a 2020 study on due diligence undertaken for the European Commission. ${ }^{8}$

Securing the contribution of business to a sustainable future can be formulated as enabling sustainable value creation within planetary boundaries. ${ }^{9}$ A key aspect of

4. The European Commission, Communication from the Commission to the European Parliament, the European Council, the Council, the European Economic and Social Committee and the Committee of the Regions: The European Green Deal, 11 December 2019, COM (2019) 640 final. Quote from F. Simon and S. Morgan, 'Green Deal Branded as "Hallmark" of New European Commission', Euractiv, 11 September 2019, www.euractiv.com/section/energy-environment/news/ green-deal-branded-as-hallmark-of-new-european-commission/.

5. As included in the proposal for a new Corporate Sustainability Reporting Directive, 21 April 2021, Corporate Sustainability Reporting Directive, put forward on 21 April 2021, https://ec.europa.eu/info/businesseconomy-euro/company-reporting-and-auditing/company-reporting/ corporate-sustainability-reporting_en.

6. M.B. Taylor, Litigating Sustainability - Towards a Taxonomy of Counter-Corporate Litigation. University of Oslo Faculty of Law Research Paper No. 2020-08, 3 February 2020, https://ssrn.com/ abstract=3530768 or http://dx.doi.org/10.2139/ssrn.3530768.

\section{Ibid.}

8. Lise Smit et al. for the European Commission, Study on due diligence requirements through the supply chain, final report, 20 February 2020, https://op.europa.eu/sv/publication-detail/-/publication/ 8ba0a8fd-4c83-11ea-b8b7-01aa75ed71a1/language-en (last accessed 21 February 2021).

9. The recognition of planetary boundaries reflects the growing scientific understanding that life and its physical environment co-evolve. This concept brings together evidence of rising and interconnected global risks in several different contexts where environmental processes are being changed by human activities. Flagging a set of sustainability-critical issues presents policymakers with a dashboard of issues that arise from the collective impacts of humanity, impacts that are changing the fundamental dynamics of the Earth system on which humans rely for their lives and livelihoods. J. Rockström, W. Steffen, K. Noone, A. Persson, F.S.I. Chapin, E. Lambin, T. Lenton, M. Scheffer, C. Folke, H.J. Schellnhuber, B. Nykvist, C. de Wit, T. Hughes, S. van der Leeuw, H. Rodhe, S. Sörlin, P. Snyder, R. Costanza, U. Svedin, M. Falkenmark, L. Karlberg, R. Corell, V. Fabry, J. Hansen, B. Walker, D. Liverman, K. Richardson, P. Crutzen \& J. Foley, 'Planetary Boundaries: Exploring the Safe Operating Space for Humanity', 14 Ecology and Society (2009); W. Steffen, K. Richardson, J. Rockström, S.E. Cornell, I. Fetzer, E.M. Bennett, R. Biggs, S.R. Carpenter, W. de Vries, C.A. de Wit, ensuring the capacity for business to create sustainable value within planetary boundaries is the establishment of regulatory coherence. The EU has a key role to play here, because, as the Commission writes in its Green Deal communication, 'As the world's largest single market, the EU can set standards that apply across global value chains'. ${ }^{10}$ The EU, therefore, has a profound impact on the conduct of business through international standards and through its regulation of European business.

In line with the impact of the EU on international standards, the EU-funded ${ }^{11}$ project Sustainable Market Actors for Responsible Trade (SMART, 2016-2020) aimed to improve regulatory coherence with regard to sustainability. The core objective of the SMART team, consisting of 25 partner institutions and a multidisciplinary team of over 70 scholars, was to conduct research aimed at facilitating market actors' contribution to a sustainable development within planetary boundaries, with greater policy coherence for development as a common thread.

The SMART project was based on the following three assumptions: first, successful development requires development to be sustainable. Second, the European Union's (EU's) market actors, private, public and hybrid, are crucial to achieving the EU's development goals. Third, comprehensive research into the regulatory complexity of market actors' impact on developing countries was required - through a systemic, interdisciplinary approach - to be able to identify the changes that are necessary to achieve policy coherence for sustainability. On the basis of these three assumptions, SMART undertook a systemic, thoughtfully structured and coordinated mapping and analysis, identifying regulatory barriers and possibilities for market actors' contribution to sustainability. ${ }^{12}$ This analysis also identified gaps and incoherencies in the regulatory complexity on the international, EU and jurisdiction-specific levels. ${ }^{13}$ Drawing on this multilevel analysis, we translated the concept of sustainability into innovative proposals for legal and policy reforms, to realise the potential of European market actors for creating sustainable value. The SMART results engage with EU policies concerning

C. Folke, D. Gerten, J. Heinke, G.M. Mace, L.M. Persson, V. Ramanathan, B. Reyers \& S. Sörlin, 'Planetary Boundaries: Guiding Human Development on a Changing Planet', 347 Science 1259855 (2015), DOI: $10.1126 /$ science. 1259855 .

10. The European Commission, Communication from the Commission to the European Parliament, the European Council, the Council, the European Economic and Social Committee and the Committee of the Regions: The European Green Deal, 11 December 2019, COM (2019) 640 final, Section 3.

11. SMART was funded under the European Union's Horizon 2020 Research and Innovation Programme call The European Union's Contribution to Global Development: In Search of Greater Policy Coherence; see www.smart.uio.no.

12. B. Sjåfjell and H. Ahlström, 'Facilitating Interdisciplinary Corporate Sustainability Research: The SMART Research Guide'. University of Oslo Faculty of Law Research Paper No. 2020-16, Nordic \& European Company Law Working Paper No. 20-07, 15 June 2020, https://ssrn.com/ abstract $=3626903$.

13. For an overview of SMART's research work packages and all publicly available reports, see www.smart.uio.no/publications/reports/. 
sustainability, including the EU Green Deal, with proposals for how to strengthen and improve the EU's initiatives. ${ }^{14}$

The SMART project, which could not have succeeded without the dedicated work of many scholars from many countries, was enriching, timely and impactful, leading to publications and reports that have been cited by the $\mathrm{UN}^{15}$ and the EU. ${ }^{16}$ The contributions to this Special Issue show how the work of many scholars helped identify means to achieve policy coherence in individual jurisdictions, in Europe and, ultimately, in relation to the operation of business worldwide. The work provided by these scholars has been an inspiration in the SMART project and continues to inspire further work in new collaborative research projects and through our international networks. ${ }^{17}$

\section{The Netherlands and the SMART Project}

In March 2018, Professor Liesbeth Enneking, co-founder of the Erasmus Research Network on Sustainable Business \& Human Rights at Erasmus School of Law, and Dr. Jeroen Veldman, Lead of the Modern Corporation Project at Bayes (formerly Cass) Business School, organised a workshop on policy coherence on sustainable trade and development. ${ }^{18}$ The workshop took place

14. B. Sjåfjell, J. Mähönen, M.B. Taylor, E. Maitre-Ekern, M. van der Velden, T. Novitz, C. Gammage, J. Cullen, M. Andhov \& R. Caranta, 'Supporting the Transition to Sustainability: SMART Reform Proposals'. University of Oslo Faculty of Law Research Paper No. 2019-63, 2019, https://papers.ssrn.com/abstract=3503310. See further smart.uio.no/ reform_proposals.

15. See, e.g., International solidarity and climate change - Report of the Independent Expert on human rights and international solidarity (A/HRC/44/44) [EN/AR/RU/ZH], Section B, Reforming Corporate Law and Practices, 1 April 2020, https://reliefweb.int/report/world/ international-solidarity-and-climate-change-report-independent-experthuman-rights-and.

16. See, e.g., Inception Assessment Sustainable Corporate Governance Ref Ares(2020)4034032 - 30/07/2020, Section D. Evidence base, data collection and better regulation instruments, https://ec.europa.eu/info/ law/better-regulation/have-your-say/initiatives/12548-Sustainablecorporate-governance_en, and Commission Staff Working Document 2019: EU report on Policy Coherence for Development, Brussels, 28 January 2019 SWD(2019) 20 final, 12-13, https://ec.europa.eu/ international-partnerships/system/files/swd-2019-20-pcdreport_en.pdf, and Commission Staff Working Document: Promote Decent Work WorldWide: Responsible Global Value Chains for a Fair, Sustainable and Resilient Recovery from the Covid-19 Crisis, Brussels, 20 October 2020 $\operatorname{SWD}(2020) 235$ final, under Section iv. Engagement with the research community.

17. Including through the SMART Network, which provided invaluable support throughout the project period, www.jus.uio.no/english/research/ areas/companies/networks/the-smart-network/.

18. The workshop's main outcomes were reported to the SMART project, an EU-funded (Horizon2020) project involving academic research that promotes sustainable development within the planetary boundaries. By providing a country mapping of relevant rules and policies in the Netherlands, the workshop helped to further the SMART project's dual aim of 1) identifying the degree of policy coherence between the EU and its member states with regard to relevant rules and regulations related to trade, investment, corporate governance, etc. and 2) determining whether and how this coherence is reflected in the implementation of at Erasmus University Rotterdam within the framework of the 'Dynamics of Inclusive Prosperity' Initiative, which is the focal point of Erasmus University's research into ways to enable as many people as possible to benefit from increasing prosperity while minimising the negative consequences. To identify whether and in what way domestic and transnational legal and policy instruments are coherent, the workshop reviewed relevant rules, case law and policies in various fields of the Dutch legal and policy framework. To provide a multiperspective view of relevant legal and policy issues and development, with a focus on gaps and/or best practices, these policy instruments were considered in relation to relevant international policy frameworks like the UN SDGs, the OECD Guidelines for Multinational Enterprises and the UN Guiding Principles on Business and Human Rights.

The Special Issue identifies a number of interesting and legally relevant developments in the Netherlands, including the International Responsible Business Conduct Agreements $\left(\right.$ Scheltema $\left.^{19}\right)$, the Dutch Child Labour Due Diligence Act (Enneking ${ }^{20}$ ) and a new model text for bilateral investment treaties (Arcuri and Verbeek $^{21}$ ). Lokin and Veldman take a comprehensive look at soft and hard law institutions in the Netherlands that enhances the possibilities for safeguarding stakeholders' interests and sustainability in the Netherlands. $^{22}$ In terms of ex post facto dispute resolution between third parties, Enneking ${ }^{23}$ addresses recent judgments in a number of civil liability cases, and Van 't Foort provides an overview of decisions rendered by the Dutch National Contact Point in relation to complaints filed over alleged violations by Dutch companies of the norms set out in the OECD Guidelines. ${ }^{24}$ Van Wingerde and Bisschop explore the limited potential of such resolutions by exploring two case studies in the global waste industry. ${ }^{25}$ And, finally, Cseres explores how regulatory interventions to promote Responsible Business Conduct (RBC) in global value chains may be directed at consumers. ${ }^{26}$

those rules by companies, both at home and throughout their global value chains. The input provided by this workshop is reflected in the SMART Project's reform proposals.

19. M. Scheltema, 'The Dutch International Responsible Business Conduct Agreements: Effective Initiatives?' 2019/4 Erasmus Law Review (2019).

20. L. Enneking, 'Putting the Dutch Child Labour Due Diligence Act into Perspective', 2019/4 Erasmus Law Review (2019).

21. A. Arcuri and B.J. Verbeek, 'The New Dutch Model Investment Agreement: On the Road to Sustainability or Keeping up Appearances?', 2019/4 Erasmus Law Review (2019).

22. M. Lokin and J. Veldman, 'The Potential of the Dutch Corporate Governance Model for Sustainable Governance and Long Term Stakeholder Value', 2019/4 Erasmus Law Review (2019).

23. L. Enneking, 'Putting the Dutch Child Labour Due Diligence Act into Perspective', 2019/4 Erasmus Law Review (2019).

24. S. Van 't Foort, 'Due Diligence and Supply Chain Responsibilities in Specific Instances', 2019/4 Erasmus Law Review (2019).

25. K. Van Wingerde and L. Bisschop, 'Waste Away. Examining Systemic Drivers of Global Waste Trafficking Based on a Comparative Analysis of Two Dutch Cases', 2019/4 Erasmus Law Review (2019).

26. K. Cseres, 'Consumer Social Responsibility in Dutch Law: A Case Study on the Role of Consumers in Energy Transition', 2019/4 Erasmus Law Review (2019). 
Together, the contributions in this Special Issue provide a comprehensive overview of issues concerning policy coherence in relation to fostering environmentally and socially sustainable business in global value chains from a Dutch perspective. Furthermore, the contributions show how the policy framework relating to sustainable development and RBC in global value chains increasingly goes beyond 'do no harm' and is accompanied by an expanding catalogue of behavioural standards for both state and corporate actors. As such, the contributions draw attention to the increasing role of states as ultimate guarantors of the standards set out for responsible business behaviour. And, finally, the contributions make it possible to identify relevant developments and institutions in the Netherlands, including rules and regulations related to trade, investment and corporate governance as well as cases related to corporate and consumer responsibilities, and to assess their role in relation to the potential to provide a positive response to the concern about the human and environmental impacts of business activities.

By delivering a comprehensive view of proposals in the Netherlands that aim to improve engagement with regard to $\mathrm{RBC}$ in global value chains and sustainable development and by addressing the coherence between these proposals and EU policies, the contributions in this Special Issue contributed directly to the SMART project.

\section{Concluding Reflections: SMART and Beyond}

To facilitate the transition of European business to sustainability and to ensure that Europe has the market leaders of tomorrow, it is crucial that we achieve a transition that ensures a safe and just space for humanity. To enable market actors to contribute to a sustainable future, the SMART proposals draw on commonly agreed upon sustainability goals and sustainability science $^{27}$ to deliver a set of reform proposals aimed at changing the way business and finance operate and the way products are produced and consumed ${ }^{28}$ by integrating the principle of sustainability into all policy areas. ${ }^{29}$

27. J. Rockström et al., 'Planetary Boundaries: Exploring the Safe Operating Space for Humanity', 14 Ecology and Society 32 (2009); Steffen et al., above n. 9; M. Leach, K. Raworth \& J. Rockström, 'Between Social and Planetary Boundaries: Navigating Pathways in the Safe and Just Space for Humanity', in World Social Science Report 2013 (2013), at 84-90; B. Sjåfjell, T. Häyhä \& S. Cornell, 'A Research-Based Approach to the UN Sustainable Development Goals. A Prerequisite to Sustainable Business'. University of Oslo Faculty of Law Research Paper No. 2020-02, 28 January 2020, https://ssrn.com/abstract=3526744 or http:// dx.doi.org/10.2139/ssrn.3526744.

28. B. Sjåfjell et al. 2019. 'Supporting the Transition to Sustainability: SMART Reform Proposals'. University of Oslo Faculty of Law Research Paper No. 2019-63. https://papers.ssrn.com/abstract=3503310.

29. B. Sjåfjell and H. Ahlström, 'Facilitating Interdisciplinary Corporate Sustainability Research: The SMART Research Guide'. University of Oslo Faculty of Law Research Paper No. 2020-16, Nordic \& European Com-
At the heart of the SMART reform proposals is the suggestion to redefine the overarching corporate purpose as sustainable value creation within planetary boundaries. Followed up by clearly defined rules for sustainability assessment, notably including mandatory sustainability due diligence, risk management would be improved, as would legal certainty for business in the sense that it would clarify what the boundaries of legitimate business activities and thus the extent of the vulnerabilities of the business are. These proposals aim to give the sustainability-oriented businesses in Europe, of which there are many, a competitive advantage over unsustainable business.

This Special Issue shows how individual initiatives by national legislators ${ }^{30}$ can be inspiring examples, as they have been for the SMART project's analyses and proposals. Yet national initiatives also bring with them challenges including questions of scope and of legal certainty for businesses, specifically with regard to crossborder operations and activities. Today, business is confronted with a plethora of fragmented requirements in and between the jurisdictions in which they operate or are registered and are, additionally, subject to influential international guidance such as the UN Guiding Principles on Business and Human Rights and the OECD Guidelines for Multinational Enterprises. This leaves business with the difficult task of figuring out the various requirements and expectations and may lead to regulatory competition between EU member states. Harmonisation on the EU level would bring the benefits of simplification, clarity and legal certainty.

At the time of writing, the EU Commission has not yet put forward its proposal for a directive under the Sustainable Corporate Governance initiative, ${ }^{31}$ which is expected to engage to some extent with the company law duties of corporate boards ${ }^{32}$ and which most probably will contain mandatory sustainability due diligence requirements. There has never been a stronger case for all partners working together for a better system, and the way out of the Covid-19 pandemic must also be a path to sustainability. The EU, as a global actor and as European policymaker and legislator, has the crucial role of ensuring that the international and European

pany Law Working Paper No. 20-07, 15 June 2020, https://ssrn.com/ abstract $=3626903$.

30. C. Macchi and C. Bright, 'Hardening Soft Law: The Implementation of Human Rights Due Diligence Requirements in Domestic Legislation. Forthcoming in M. Buscemi, N. Lazzerini \& L. Magi (eds.), Legal Sources in Business and Human Rights - Evolving Dynamics in International and European Law (Brill, 2020)', 22 October 2019, https://ssrn.com/ abstract=3524488 or http://dx.doi.org/10.2139/ssrn.3524488.

31. See the European Commission's Sustainable Corporate Governance initiative here: https://ec.europa.eu/info/law/better-regulation/haveyour-say/initiatives/12548-Sustainable-corporate-governance_en, and the call for action from the Commission by the European Parliament here: 'Companies Must Protect Human Rights and Environment within their Value Chains', March 2021, www.europarl.europa.eu/news/en/ agenda/briefing/2021-03-08/5/companies-must-protect-humanrights-and-environment-within-their-value-chains.

32. Connecting also with the proposal for Corporate Sustainability Reporting Directive of 21 April 2021, https://ec.europa.eu/info/businesseconomy-euro/company-reporting-and-auditing/company-reporting/ corporate-sustainability-reporting_en. 
regulatory framework for business mitigates the financial risks of unsustainability as far as possible. However much effort is invested by front-runner states, such as the Netherlands, the way forward lies through European harmonisation.

The risks of continuing on an unsustainable path of business as usual are enormous. And so is the potential that lies in securing a transition to a sustainable future within planetary boundaries. 